\title{
The Folk Life of Afghanistan.
}

\author{
Ikbal Ali Shah M.R.A.S. F.R.G.S.
}

To cite this article: Ikbal Ali Shah M.R.A.S. F.R.G.S. (1919) The Folk Life of Afghanistan., Folklore, 30:4, 249-281, DOI: 10.1080/0015587X.1919.9719109

To link to this article: http://dx.doi.org/10.1080/0015587X.1919.9719109

$$
\text { 曲 Published online: } 01 \text { Feb } 2012 .
$$

Submit your article to this journal ๔

Q View related articles $\sqsubset$ 


\section{Jfolk= Lote.}

TRANSACTIONS OF THE FOLK.LORE SOCIETY.

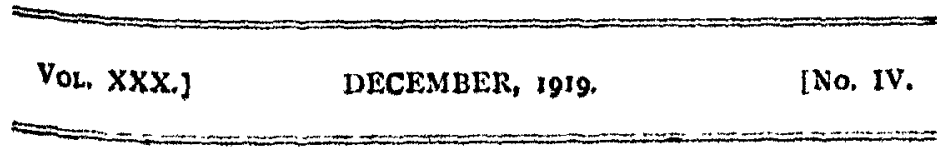

\section{THE FOLK LIFE OF AFGHANISTAN.}

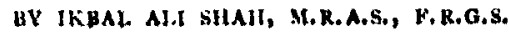

(Read before the Society, Junc I8, 1919.)

"ONE touch of nature," as Shakespeare has said, "makes the whole world kin." It is my intention, therefore, to deal with my subject so as to make this kinship felt. Customs and what are called "superstitions" may differ in various countries, but they arc, in every case, associated with natural instincts and are in a sense an expression of this instinct. Behind this we see humanity groping blindly with the mysterics that surround our lives as the firmament scems to surround the globe. Some superstitions are radiant as sunlight : others dark as night, put yet glorious with stars, for all folk customs have in them the element of human kindliness and sympathy, and especially so when they are performed for the bencfit of: others-the weak and the frail, threatened by perils, the old friend or relative about to dic and the child who, help. less and how beautiful, is arising like a heavenly orb in the dawn of human consciousness.

In the West you have formulated a science which deals, vol., $\mathrm{x} \times \mathrm{x}$. 


\section{0 \\ The Folk Life of Afghanistan.}

with folk-lore, and some would have us believe that the intellectual life of primitive peoples has evolved by a process governed by natural laws ; others object to drawing analogies from biological evolution, and contend that the folk life of separated peoples is the result of the reaction of the human mind on its environment and that there are strictly local belicfs and practices-in short, that every belief has an area of origin and is part of the history of a people rather than the product of a natural law-a dis. tinction with a difference. But it is not my intention to enter on any controversial aspect of the subject. I prefer simply to act the part of the recorder and tell you of those things I have seen and of which I have heard, leaving the data accumulated to be dealt with in accordance with whatever fashion of thinking is favoured by individual hearers. My subject is the folk life of Afghanistan, the customs as well as the lore, and the matter is sufficiently bulky to occupy our attention in the time at my disposal. I have found it necessary to limit the survey. Festivals, for instance, cannot be dealt with at any length, but as many of those are Islamic and resemble those held elsewhere, having been imported, you will agree, I think, that it is better that I should confine my attention chiefly to those domestic customs and beliefs which are not generally known. I ask you, therefore, to step with me into the Afghan family circle and to share, for a time, its interests and cspecially in so far as they are of import to students of folk-lore-for the time being, I shall ask you to dismiss from your minds the Afghan as a fighting man and to bo introduced to him as a peaceful householder. As you will find, there is a good deal of human nature in the picturesque individual and much in his family circle.

I shall begin with birth, pass through the years of youth to the marriage ceremony and follow the individual to the deathbed, so that you may acquaint yourselves, if only in outline, with the life history of an Afghan.

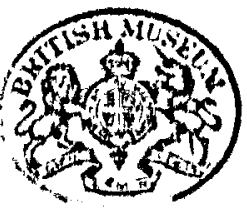


Even beforc he enters the world the Afghan creates a stir., Preparations are made for his arrival becauso ceremonies have to be performed which will, as is believed, excrcise an influence on his future life. The mother-to-be is confined to her room in the eighth month or even earlier, according to the state of her health, and she is watched over by mid-wives. These mid-wives are not trained, as is the case in the West. A woman practises because her mother was a mid.wife, and although her knowledge as a nurse may be limited-too severely limited in not a few cases-she is invariably expert in a sense that the folk-lorist understands, and, I am afraid, is inclined to encourage, if the truth be confessed.

Relatives begin to arrive a few days before the birth is due. When it becomes known that the birth is imminent, others arrive, the men armed with matchlocks. When it is announced to those waiting outside the house, that the babe is born, the guns are fired, tom-toms are beaten, and the players of musical instruments set up a clamour at once shrill and deafening. But everyone strikes the appropriate human note, "Happy and prosperous be your days!" each says to the other. "Happy and prosperous be your days!" is the wish expressed on behalf of the new.born babe too. The guns and tom-toms scare away all evil infuences; the good wishes are productive of good in. fluences. All hearts are opened in this time of rejoicing and congratulation for a living mother and a living. child, and buckets of grain are distributed to the poor. The imagination as well as the heart of the Afghan is touched by the mystery and crisis of birth.

In, connection with the shooting, this is a well-defined custom. If the babe is a girl, seven or five shots are fired, but, if a boy, fourtecen shots or cven more. It matters not. about what time of the day or night the birth takes place, The clamour is as loud in the darkness as in the daylight. Na one in an Afghan village requires to whit for a morning 
paper to advertise the hour and place of birth; often in the dead of night people are awakened by the birth demonstration, only, however, to repeat one to another the appropriate good wish, "Happy and prosperous be your days !"

The date and hour of the child's birth is of great consequence. Friday is a lucky birthday. Happy is the babe who sees the light on that day. A child born at early morning is assured of success in life; a child born in a storm is expected to endure ill-health or to have to face other troubles in the days to come. Sometimes children are named after the month of birth-one named Ramzanni, for instance, is one born in the month of Ramazan-the month of fasting.

When the child is born intimation must speedily be made to relatives residing at a distance. Servants of the household mount their horses and gallop away at full speed to tell the glad tidings. Their steps are hastened by the knowledge that they will receive rewards of money and silk turbans from those to whom they are going.

In the houschold both father and mother are heartily congratulated. Then all, except the houschold guests, retire. These guests are expected to assist in attending to mother and child. Each female, as a rule, has some special remedy to offer to restore the strength of the mother. The commonest cure is a safe and sensible enough one. It is called ajwănl, and is a soup made of ajowan seeds (carum' copticum), caraway seeds, sliced ginger; cloves, meat, chicken, sugar. It is boiled until the fibres of the theat disappear in the mixture. The soup is given to the mother every three or four hours, being froshly prepared each time: The apartment is kept dimly lighted and well heated. In a corner stands a pedestal with :a dish in which burns incense of Benzoin and Joss sticks. For some weeks no visitor is expected to enter the house: They may obtain news of the mother and child's progress at the door or from servants who bear messages. 
During the first two months the child is wrapped in a silken quilt over which is a white cloth inscribed with sacred verses from the Koran, worked in black silk. A thick silk or cotton cord is wound spirally from neck to toe about the child. The cradle is a sort of hammock made of thick Persian carpet, and is gently swung to lull the babe to sleep. It is extremely unlucky, by the way, to swing an empty cradle.

If the mother's milk is deficient, a wet nurse is engaged. Much care is taken in selecting her. Her character must be above reproach. She must be of good parentage and her husband must be honest and brave-one who has never fled in battle or ever been wounded on the back. The wet nurse is given a special diet and is greatly honoured by the servants.

The first ceremony is performed by the Imam or Mulla of the district. He comes and reads in a loud voice into both ears of the child a prayer which is as follows :

$$
\begin{aligned}
& \text { "Allaho akbar, Allaho akbar, ush hado, } \\
& \text { Ullaelaha, illulla, ush hado, una, } \\
& \text { Muhammader, rassul, ullah, Allaho } \\
& \text { Akbar, Allaho akbar." }
\end{aligned}
$$

"God is great, God is great I I am a witness that there is no God but one God, and that Muhammad is His Prophet. God is great, God is great !"

The popular belief is that a child is born without a faith, and that if this prayer is not repeated in his ears, then he is no Moslem, although born of Moslem parents.

For his service the Mulla receives a silk turban, some money and sweetmeats.

When the child is five or six months old the naming cercmony is performed. It is attended by blood relatives. The Mulla, or the spiritual leader of a Sufi order, is called, or, failing one of those, an elder or a poet pronounces the ful] name. The surname, be it understood, need not 
necessarily be that borne by the father. A man named Fateh Khan, for instance, may name his son Ahmad Shah, or Nabi Jan, or the like. Among the better classes two names are given: one the ordinary name for the household, the other the Literary or Birth Date name. The two names may perchance be run together and pronounced as one. In a special code of Persian, every letter in the alphabet is numbered. If the numbers of the Date Name arc added the total will give the ycar of birth. Only males can receive a Date Name. It is not customary for ladies to have more than one name and, of course, if it is beautiful enough, one is really quite sufficient.

When a few months old, the Head-shaving ceremony is performed by the family barber. The child is dressed in gaudy clothing; the barber spreads an embroidered hand. kerchief, wets the hair with rose water from a silver cup and shaves with a new razor. This practice has originated in the belief that the hair of a now born child is unclean.

Friends and relatives attend the ceremony. They dine after the barber does his part, and are afterwards enter. tained to a musical programme. While the instrumentalists are engaged the barber presents the silver cup that held the rose water and each gucst drops a coin into it. All the coins must be silver, and they all go to the barber's banking account. The shaving is repeated time and again until the child is four or five years old. The first shaving alone, however, is a ceremonial one.

The dread of the Evil Eye is prevalent. The foster mother must observe strict rules to avert its influence. When the child is taken outside the house special precautions are taken. On no account must it be taken out at night, and certainly never on a Thursday night, as the evil spirits are particularly malevolent on that night. The nurse must not eat any white cereal, such as rice, outside on a starry night. The star-eyes are dangerous. The baby should not be taken out when the sun is shining brightly 


\section{The Folk Life of Afghanistan.}

at noon, not because of fear of sunstroke, but because vultures and other birds of prey may at that hour drop eggs of corrosive liquid on the child.

When a thunderstorm rages, the child is supposed to be in special danger. Lightning strikes an only child. It is important that the baby should, when carried out-of-doors, be kept from the evil gaze of beggars, criminals and others of ill repute. The face is veiled. I observe that babies are similarly protected in this country although the signif. cance of the custom is probably lost except in rural districts.

When an Afghan has passed his second year, a juvenile function takes place. Small boys of eight or nine years of age are assembled and march together to the house of the parents, there to sing together in praise of mother and child and to invoke blessings on both. Each boy receives a gift.

When a child is cutting its teeth, the event is celcbrated by a gathering of relatives. In time, when the milk teeth begin to come out, they are thrown into a mouse hole so that the new teeth may be sharp and strong as those of a mouse.

The child is kept on milk diet until about three years of age. Then it is put on "grain and hard diet." The occasion is celebrated in ceremonial manner. The family collects in a room and the parents recite long passages from the Korann, Then the child's neck is adorned by charms, including luck stones, luck wood and the carved claw of a lion or tiger. In addition to the charms, a sacred pendant is worn: the pendant for a girl is more ornamented than that given to a boy. The sacred pendant may be a coin, or a picce of metal inscribed, or perhaps a jewel attached to gold or silver chains. For a year or two the child is freed from ceremonials. When, however, a new dress is put on, a visit is paid to relatives who drop coins into the pockets.

A boy's education begins at eight or nine. Ho may attend a Mosque school or a public school, which is partly 
supported by the Government. The books used are prepared by educationists, chiefly notable Mullas, and the Mullas appoint the teachers. Every village has its school. The more important towns, such as Kabul, Kandahar, Ghazni and Herat have large and well-organised educational institutions, the more advanced being somewhat like Western Universities. In these a training is given in the more important Oriental languages. Science is not neglected, but religious philosophy bulks largely in the curriculum. Sufis and Mullas have almost complete control of these universities, which are attended by students from many lands. The schools at Badakshan, a town on the borders of Afghanistan and Turkistan, are attended by many students from Bokhara.

I now come to the betrothal and wedding customs and ceremonies. The contracting parties do not act on their own account. There is no preliminary love-making period as in the West, but as arranged between parents or guardian, a proceeding not entirely unknown in the West. The young people have no opportunity of making advances or proposals. Purda (seclusion) makes it impossible for the young people to meet. When a boy is advancing in his teens, his parents open negotiations with the parents of some coy maid who had been discovered by some woman hired to play the part of social spy. This lady, who keeps her engagement secret, visits various houses and reports to the gentleman who has engaged her on the habits and manners of families, on the beauty and behaviour of possible brides, and, last but not least, on the financial position of parents of desirable girls. The pedigrees of a girl's father and mother are scrutinized, and, if the parents are dead all particulars regarding the cause of death and their ages when they passed away. If a beautiful orphan had parents who died of some disease, there is hesitation about contracting a family alliance. The Afghan gives some consideration to eugenics. 
Of great importance is the question of class, and of great importance the question of sect. Men with long pedigrecs do not wish their sons to marry the daughters of upstarts. Shias will not intermarry with Sunis, for, although both sects are Islamic, there is a gulf between them as there is between Protestants and Roman Catholics in the Christian world. Shlas are of Persian extraction and are called Quzilbashi or merely Quzilbash. Then Sycds will not give a daughter except to a Syed. Syeds are direct descendants of the prophet Muhammad. A Muslim girl will not wed a Hindu although there are Hindus in Kabul. Spiritual leaders, i.e. PIrs or Súfis, will not give their daughters to a commoner. The young man must however, belong to the family of another spiritual leader.

When all conditions are given consideration to and a likely bride is found, the parents of the young man take action. First of all the existing friendship is cultivated, the motive, however, being well concealed. Even when the parties concerned know what is coming, nothing is said regarding marriage for some time. Indeed, one or two years may go past before they talk business. During the interval there may be frequent visits, banquets and the exchange of gifts. It may be that the young man's mother may show a special interest in the girl, and she may give her a gift or two from time to time.

When at length the negotiations are formally opened, a party of ladies will visit the girl's mother. The mother of the young man may begin by saying, "Your second daughter is, by the Grace of Allah, very beautiful. She is well behaved. She is clever withal. My husband and I have often expressed our admiration for your daughter. Indeed, my husband has even suggested that we might approach you with the proposal that our houses should be allied by the marriage of our children. My son, by the mercy of God, is well educated and he has manly qualities. If an alliance can be formed, I am assured that my son will 
always be meek and obedient to you and that he will make and keep your daughter happy. Gentle is his spirit: he would be as dust on which your daughter may tread." (I may interject here that the young men of Afghanistan aro not particularly meek or gentle.)

When this speech is uttered, the ladies who have accompanied the young man's mother speak in his praise. Some praise the girl and her mother.

At this conference the girl's mother says very little. She sits listening with downcast eyes, betraying no emotion, and in the end very gracefully expresses thanks for all that has been said. She urges that there is no haste for marriage. Both lad and lass are still young and do not understand the Nashaib and Faraz of this world-that is, the ups and downs of life. She promises, however, to consult her husband, and then the party is invited to remain and partake of food and entertainment. This mecting is called Dukhtar Talabi, or " Daughter-Seeking."

For some months the negotiations may not be advanced further. Delay, however, is promising. If there is to bc a refusal, it is made promptly but politely, a common excuse being that the girl is delicate and unable to undertake household duties, or, it may be, the mother pleads her inability to part with her daughter. Excuses are casily framed.

When some time has passed and no answer is received, a servant may be sent to the house of the girl's parents bearing a message in the nature of a reminder. A vague answer may be returned. Indeed, several vague answers may be given to several successive reminders. A monthly message is sent at first. Then comes a fortnightly one. Meanwhile, the girl's parents are making enquiries regarding the parents, and even when they are satisfied that the prospects are good, they hesitate so that the girl may be all the more highly valued, being difficult to get.

There is an Afghan saying in this connection, "That 


\section{The Folk Life of Afghanistan.}

consent is not given until the young man's people wear their shoes by paying calls until the soles are as thin as the thin layer of an onion." The negotiations have all the while to be delicately managed. A slight error of judgment or action may shatter all hope of effecting an alliance.

In the end, if all goes well, the young man is accepted by the girl's parents in their daughter's nominal Ghulami (slavery). Then a day is arranged when the members of the young man's family will attend at the home of the prospective bride the ceremony of Qand Shikini-a name derived from Persian Qand, loaf sugar in cones, and Shikini, the action of breaking. This sugar-breaking ceremony is the Betrothal ceremony.

The mother of the girl invites near relatives to the house, and these and the near relatives of the young man arrive with gifts, which are carricd in trays by servants who march in procession perhaps with a band. The youths of the party fire guns, and the procession thus arrives in great style. Round the girl's house the trees are hung with lanterns and ornaments. Inside Persian carpets are spread, and on these are great cushions on which the gucsts are to recline. A Mahfil is held while the guests arrive, Mahfil signifying a scene of mirth and song.

The greetings are warm and delightful. "Khush Amadi," they say, "Manda Nabashi," that is "Happy your coming,", and "We hope you are not weary."

The ladies join the Mahfil, and if the weather is warm Sharbat is brought in crystal jars and served in crystal tumblers. In winter, green tea is handed round.

In time all retire. Then there is a formal re-entry into the hall. Women are veiled and the men come in. Then a grandfather stands up and takes from each tray the gifts, announcing what they are and who has presented them. Then the father of the young man comes from a corner holding a tray over his head. This tray is covered with red silk embroidered with gold. He places it at the 
grandfather's feet, saying, "Mr. so and so has kindly consented to take my son as the slave of his daughter. In this tray I have loaf-sugar cones. By breaking one against the other the promise of Mr. so and so will be sealed."

The old man uncovers the cones, of which there are four, each about eighteen inches high and six inches in circum. ference at the base. He calls on the company to raise their hands for prayer so that the young pcople may have happiness. Each repeats a silent prayer. Then one cone is struck against the other and broken. If there are many fragments that is a good sign. A general chorus of greetings is immediately raised. Voices call loudly, "Mubärak"- "Be it happy !" Small pieces of the sugar are snatched by boys and maidens. Another prayer follows when all have become silent again.

There is no further ceremony - no engagement ring. The guests remain and make merry. Some remain all night. Meanwhile, the girl who is to be married sits in her room. No one is allowed to see her but her old nurse and her playmates.

Next day, the guests are entertained at the house of the young man's mother. More presents are exchanged. The young man's tutor receives a white turban, and his mother a silk dress.

Before the marriage date is fixed, there are frequent visits to both houses and fruit offerings are made. The party carrying fruit to the house of the girl's father is formally welcomed and the servants get awards.

The girl is meanwhile serving an apprenticeship in the kitchen, acting as senior assistant to her mother. In her spare time she makes gold-thread hats for her father and brothers. She is not happy as a rule. The thought of leaving the house of her parents weighs heavily on mind and heirt, and often she shuts herself in her room and weeps long and bitterly. Her mother cannot help being affected by the girl's sorrow. They love one another very' 
dearly, and the time of parting is at hand-often very real parting, for the girl may be going some distance away to the house of her husband, which for a time will be very lonely.

When the wedding date is arranged, there is a ceremonial visit and financial matters are discussed. It is regarded as a good omen if the morning of this visit is fine and dry, which is usually the case.

The girl's parents arrange the date, and the visiting party agree to it. "We shall," they say, "give our boy to your daughter's slavery on such and such a day."

\section{Ceremonies and Customs Before, At, and After Marriage.}

The date which is mutually agreed upon gives them a clear margin of six to eight months. Most marriages are arranged to be held in winter rather than in summer. In the province of Herat, one can trace a Persian influence, in 80 far as they prefer to hold matrimonial festivals during nuroz time. Nuroz is generally celebrated in Persia, and has its origin in that country. It is associated with the coming of the winter sun, and Farasis, or, as they are now called, Parsis, pay much attention to the Sun, the ancient worship of which was closely related to customs connected with the sect of atish parast or Firc Worshippers.

In these months of preparation much work is done, so as to prepare a comfortable home for the young couple. A large dowry is expected, and given. Indeed, some houses are almost emptied so that the daughter may make a grand show at the wedding.

Women are employed to prepare clothing for the bride and bride-groom, and the whole household is meanwhile kept busy adding to the number of the articles, which are to be given. Women sew and do embroidery, and the father and brothers visit different shops, in their city or in 
other towns, to purchase such household necessities as the ladies may ask them to procure.

Ladies of the family are requested to spare an hour or two each day so as to help in sewing the bride's trousseau, others are commissioned to do work at their homes. They all work by day and by night. In the courtyard, or over a plitform round a fountain, one can sce them sitting on, Persian carpets cutting, sewing, or putting wool and cotton in the bed mattresses. On one side, five or six have a large quilt to sew, and there are cups of green tea by their sides. The young girls are engaged in the less elaborate needlework, others of maturer age, who are greatly skilled, are given the difficult things to do.

While we are at the dowry, it may be of interest to detail the gifts which a mother allots to her daughter. A sum of moncy, a piece of land, a garden or a house are given in addition to the following articles:-

(1) Wearing apparel, consisting of three pieces, in white cotton intended for sunmer use

50 to 100

(2) Wearing apparel, silk (coloured)

5 to 20

(3) Richly decorated apparel (coloured)

5 to 20

(4) Highly embroidered sheets for wrap. ping the body

(5) Shoes (ordinary)

5 to 20

(6) Decorated shoes

5 pairs

(7) Shawls

2 pairs

(8) Fur coat for the bridegroom

5

(9) Linen sheets for the floor

1

10

(Io) Carpets

5

(II) Bed sheets

10

(I2) Quilts

5

(I3) Crockery

No limit

(14) Glassware

No limit

(15) Jewellery

No limit

(16) Big roller cushions

(17) Curtains 
(18) Table covers (white)

10 to 30

(19) Table covers (prints)

10 to 30

(20) Kitchen utensils and other accessories.

Sometimes as many as 150 pieces

No limit

(21) Handkerchiefs, socks, muffers, caps, powder-boxes (face powder), mirrors, decorative articles, prayer carpets, clocks, etc., etc.

The young couple are provided with an almost complete household outfit, which should last them for fifteen years. A good few carts are necessary to convey everything. The prevalent idea is "that we ought to set the young people on their feet till they may be able to support themselves."

In addition to those mentioned, there are presents given on behalf of the mother of the bride to the bride.groom. Thesic are fewer, and are useful-turbans, a fur coat, suits of clothing, shoes, one or two horses, and guns.

Meanwhile the mother of the bride-groom is also busy with her preparations, although she has to provide less than the bride's mother. She and her husband must give wedding presents to the bride too. The articles they offer are few but costly, and include one very gaudy and highly embroidered garment, a pair of shawls and golden shoes. The jewellery given by the bride'groom's people comprises a ring, a pair of bracelets, a string of pearls and other stones, and a pair of pazäb (big hollow rings for the fect, with small bullets hanging all round). Pazab is from the Persian, $p a-f e c t ; \varepsilon a b$-from zabidan, becoming (bccoming fect).

These presents in jewellery run away with a little fortune. All the gifts must be first-class in style and of great value, and gold is one of the necessary clements. Not infre. quently, the same pieces of jewellery pass from generation to gencration. They send their old ornaments to be polished and cleaned, and they are passed on as brand new ones, specially manufactured for the latest recipients. The poorer classes cannot make a great display, and their 
jewellery is mostly of silver with one or two pieces of gold. As soon as outside members of the Clan are informed of the wedding, they procure or prepare presents for the bride and the bridc-groom also. They give them to the opposite parties, a brother of the bride's mother will give presents to the bride-groom, whilc a lady who may be a sister of the bride-groom's father will bring her presents for the bride.

There are no hard and fast rules as to those gucsts who are not very intimately related to the young people; they may or may not give presents. Some friends offer coin of silver or gold.

About two or three months prior to the date of the marriage, invitations are sent far and wide. A poet is requested to versify a form of invitation. It consists of from twenty to thirty couplets; and is written with golden ink on a red glazed paper with floral designs on the margin. It bears no family crest-which are not commonly used-and begins like other Muslim writings with either? "God is great," or "By the name of the Allah, the com. passionate, the merciful!" Under this text is the date. of the marriage, the address and the name of the bride* groom, but not of the bride, who is referred to as "the daughter of So-and-so." Modesty prevents disclosure of the name of the lady. It is of intercst to note that thesc invitations are sent out by the bride-groom's parents and not on behalf of the bride's penple. The announcement: reads something like the following:-

"By the name of the Allah, the Compassionate, the merciful!

Muhammad Khan, the ' light of the eyes '.of Yãküb Khản, is. to be married to the daughter of Yassin Khan. The datẹ. of this lucky event is Ioth of Shaban. Your participation. in the functions and ceremonies, will for ever place us under. your honourable obligation. We spread our eycs under your feet. 
Poem.

The stormy winter is far away, the spring has spread the green carpet of verdure over hills and dales. Already the buds have discarded their brownish winter coats, and the branches of the trees are no longer bare. The birds with their sweet songs have brought joy to the leafless trees, which flutter, like a bird without feathers, as the wind passes through their branches laden with the fragrance of wild flowers. The sun has poured gold in the water of the rivers at sunset, and the moon has shed liquid silver on the crystal ponds. Every heart swells with gladness.

What is it all about ?

Why! the illustrious Son ... of a pious father... is going to wed."

It might be noted in passing, that the beauty of the scene which is described above is not necessarily accurate, for it may really be snowing hard when the recipient peruses the glowing invitation. The envelopes are addressed in golden ink. No replies are neccssary, but an acknowledg. ment is always appreciated. If a man is unable to attend, he, as a rule, sends his whole family, and his wife apologises on his behalf. The invitation includes husband and wife, their children, nurses, tutors, and male and female attendants. They all have to go to the bride's house, notwithstanding that the summons was from the bride-groom's father.

A month before the date of the marriage all the arrange. ments are complete. In summer the site where tents may be pitched for the guests is levelled and put in order. The accommodation in the gilas (fort) in which the family live is not always large enough for all who are invited, as each guest. has his train of followers. Such apartments of the house which can be conveniently spared for the use of the guests are cleaned, new carpets are laid. One kitchen in the haram-saray or Ladies' Quarters, and another, a much 
larger establishment outside, are made ready. . The cooking for the wedding guests is done outside, while some dainty dishes are cooked in the haram.

A large structure like a pavilion for musical entertain. ments is erected in one of the adjoining fields. This is merely a temporary tent with wooden beams, and is of extensive dimensions. The walls of this shadi khana, "marriage house," as it is called, are made of thick and coarse cloth extending from one pole to another, the roof is supported by beams. The decorations of its interior are trappings of various colours, red predominating. At each pole is a cone-shaped globe made of abrak, a thick transparent paper like leaf gelatine or talc, and a coloured candle burns in it. There is a raised platform about five fcet broad, and expensive carpets are laid on it, while white roller pillows add to the charm of the scheme of decoration.

The entrance is like an old Egyptian archway, and a red cloth leads to the centre of the platform. Here is the Seat of Honour-the seat where the leader of the family or the head of the clan is to repose. His seat is further made comfortable by placing two or three quilts on the hard platform, above which is embroidered velvet; the Roller Pillow is larger, of a different colour to the rest, and has tassels at cach end.

At the gate of the Fort are pipers and drummers, who make loud clamour during the eventful period of three days preceding the ceremony. One batch of theseobjectionable disturbers of the peace-are posted on the roof of the Fort gate. They begin as a rule before cockcrow.

One week before the marriage the bride sceks the solitude of her chamber surrounded by her companions. She has to undergo a course of beauty treatment. Early each morning she is massaged with a paste, made of almonds, aromatic substances and flour and butter, and then has a bath. This operation is repeated in the evening. Mean, while she is put on light diet. 


\section{The Folk Life of Afghanistan.}

Two or three days before the day of the wedding the guests begin to arrive, and the rejoicing begins. The pipcrs play at the gate, other musicians entertain the men, and a few women with their small tom.toms amuse the lady guests in the Mahfil of the haram. The day before the marriage is one of grcat interest and extreme excitement. Supposing the wedding day be the roth, then, in the early hours of the 9 th, all guests rise and have breakfast together ; all make haste with it, for there is a function immediately after the breakfast. They are to convey the trousseau from the mother-in.law to the bride.

The procession is formed. $\Lambda$ band of tom-tom and pipers leading, the tray carriers are in single file; then follow the head of the Clan, the father-in-law, other elders of the Clan, then the servants, and last of all youths of the family discharging their guns. The procession is made up of men alone, all ladies in the meantime are collecting in the Hall where the presents will be received. The mother of the bride, wearing an old garment, care-worn and overWorked, runs about first in this room, then in the next, but knows not as to what she wants.

The trousseau-bearers reach their destination. This pro. cession generally adopts the longest route; it is received amidst cries of "Blessings of Allah," and the like. The head of the Clan opens the occasion with a prayer and declares that it is the desire of the father of the bride's slave that these garments should be worn by the bride at her wedding ceremony. This is, of course, a matter of form, and the mother of the bride says or rather mutters something-which none but her own ears can hear-to signify that their wishes will be complied with. The party disperses with a closing prayer.

In the meanwhile the poor girl-bride is subjected to very severe beauty treatment. Some clderly ladies massage her face, wash and put oil and perfumes on her hair. The most cruel part of the toilet is the custom of tar eadidani, 
removing of the superfluous hairs of the face. This tar zaddani is composed of Persian words,-tär, string; zaddani, art of beating-and it is effected in a curious manner.

A thin silken string is held by one lady, and brought in contact with the skin, a second lady pulls the thread out, and giving it a spin with her index finger and thumb, lets it go. It strikes the skin. The spring motion pulls the hair out, and the position of the string is changed after each stroke. It is a very painful operation, and must be performed on every lady whether she had these hairs or blemishes on her face or not. The face having been washed with warm water, without soap, is well powdered.

Then another ceremony begins, that of "bringing green grass." All the guests form a procession, led by the band and the head of the Clan : and march on to a tract of green grass on the bank of a river or a small waterway. An old gentleman has a spade which he carries on his right shoulder. He selects a place from which a patch of grass is to be dug out. The chief calls upon all to lift their hands for a short prayer, and he cuts out a small piece of the grassy earth, which is carried back. The custom is symbolical, for as the grass is grcen and fresh, so they hope that the young couple will always remain happy and prosperous.

This custom is called sabza kandan, from Persian sabsa, grcen verdure, and kandan, to cut. The piece of earth is placed in the bathroom of the bridegroom and he will stand on this grcen patch while taking his bath before the marriage. It is now lunch time, or banquet time, for there is indeed no difference in any meals served during the wedding days. Each meal is at least of eight or nine courses. All dishes are laid out and the individual is left to choose as to which he may begin first: he may start with sweets if he pleases.

Here is a menu :

I. Nan, bread. 2. Shorba, curry, with a large proportion of 
liquid, containing potatoes, curry and meat. 3. Qurma, meat fried in butter with curry, onions and flavours. No water is added. 4. Kofta, round balls of minced meat fried in butter. 5. Shami Kabdb, flat minced cakes with a layer of slices of ginger, mint, etc. 6. Biryani of Pallao, rice, boiled in meat and steamed (salt). 7. Zarda, rice (sweetened) boiled and steamed, currants, almonds added in it and coloured with saffron. 8. Firini, rice (thin pudding) like ground rice pudding (sweet). 9. Maghüt, a sweet jelly dish, flavoured with rosewater and saffron. Jo. Shir Mal, round flat cakes, slightly sweetened.

The breakfast dishes are fried chicken and samosa, sweet puffs, shir mäl and tea; at the afternoon tea nothing is eaten.

After lunch another call summons the guests to a ceremony, So-and-so is taking her presents to the bride; a procession is formed and of they go. All say khanaysh $a \mathfrak{a} \dot{a} d-$ - May this house be full and prosperous!" (Persian-

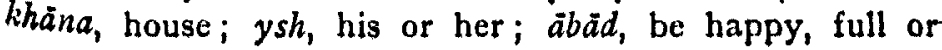
prosperous.)

A second procession is already on its way, when the call for Midday Prayer, zuhr, stops the proceedings. The time for zuhr prayer is between the hours of 1 p.m. and 3 p.m. All crowd to the Mosques, and after an hour or so the ceremony begins again.

The bride is still confined to her room, and is being beautified. The old ladies in charge dress her and see her repeatedly in her wedding clothes before she is finally passed. Her tresses are perfumed, her face powdered, her cyes are brightened, and as a finishing touch sitära (stars) are stuck here and there over her face. These "stars" or beauty-spots are small round discs, with a hole in the centre and a slit across. They are called sitaras, and are of various colours-golden, silvery, red, blue, purple and green. Crescents of the same kind are also used, and the shine on them produces a remarkable variegated effect. A eap is put on her head, and a feather fixed in it. 
The call of another prayer takes all to the Mosques for asr (afternoon) prayer, the time of this praycr is usually reckoned between the hours of $4 \mathrm{p} . \mathrm{m}$. and sunset. And after this they have to be present at the general gathering when all members of the family have brought their trays of gifts. Sweets and dried dates are thrown over the guests by the bride's people. They all sit, men on one side, and the ladies with their veils on the other. One by one they bring their trays, many pleasant remarks are made. "Ile is $a_{1}$ " one says in the midst of an announcement, " rich man, Baba." "Baba" is a word like "brethren,"-others say, "Ah, ha, this is why my uncle has been saving the gold," and so on.

Someone has not brought his gift. He docs not move to call for his trays, all look at him, the bride's father and mother feeling angry with their stingy kinsman. All at once he rises, throws his shawl ovet the bridegroom, and from under his huge coat brings out two heavy bags. He opens them and pours golden coins over the bridegroom. Then all applaud, and he makes a speech to say that he is a poor man and he would like to shower all the gold and jewels of all the earth over his relation's son, but perhaps they would gratify his humble desires by accepting what he has to give.

This function being over, afternoon tea is served. Thosc who care to retire may do so, and their meals are carried to their quarters, others have them together.

The financial strain of the wedding is in large measure placed on the bride's people. They have to erect the shadi khana, provide accommodation for the guests, and the number of the guests often reached as many as a thousand people. The cost of the food is divided between the bridegroom's father and the bride's father.

We come to the next day of the celebrations. After the morning prayer, the programme starts, the first item being the drawing up of the clauses of nikäh näma and makr 
nima. The first of the documents is a form of certificate of marriage by a $q a \bar{z} i$, and the second a legal document, in which it is clearly stated on what financial grounds the bride will stand during her married life and in case of her husband dying. Great divergence of opinion prevails in settling up the mahr näma, for often the demands of the bride's father are invariably extortionate. Elders of the family intervene as a rule and arrange matters. In the marriage contract the husband may undertake to give his wife fifty rupees a month as pocket money, a certain portion of land or a house which will be registered in her name; in the event of her husband's death she will receive I0,000 gold or silver coins. The mahr-a legal shareof the wife is of two kinds : mahr-i-mu'ajjal and mahr. i.mufassal or murwajjal.

The first of these is one which the wife can demand at any time from her husband, while the second falls to her only on the death of her husband. In cases of divorce the husband has to give up his wife's mahr, and she can claim it whether it be mufassal or mu'ajjal. All the obligations, it will be noted, are wholly on the husband's side. The girl's people do not commit themselves to any legal obligations.

An understanding being arrived at, a rough draft of the nahr näma or qabãla nâma, as it is sometimes termed, is given to the $q \bar{a} z i$ to record on parchment. The marriage certificate presents no difficulty.

The wedding ceremony is conducted in the forenoon or as early in the morning as $5 \mathrm{a} . \mathrm{m}$. A grand concert amuses the guests who sit up all night. Not even the piper on the Fort gate is allowed to snooze. Strict and parsimonious Afghans do away with singing, and other frivolous customs and a milad sharif is all that may take place.

Miledd sharif is the process of reading passages from books which deal with the birth of the Prophet Muhammad.

It is amusing to witness the watchful gucsts rousing before dawn those who have fallen asleep, so that they may 
put on their best suits, and get ready for the wedding ceremony. Some refuse to be disturbed, and if a sound slumberer is rudely aroused by a spray of cold water blows may be freely exchanged. At dawn all is ready ; the ladies pale with fatigue are arranged on one side and the men on the other. Then the bride is brought from her room, two ladies on each side of her, and she walks with slow and dignified steps to the "seat of honour." The bride-groom comes next and sits down beside her.

The $q \bar{a} z i$ with papers in his hand stands up to speak. A hush having fallen on the gathering, "Sisters and Brethren " he says, "I have here two documents, one the marriage certificate, the other mahr näma. Two gentlemen from the side of the bride and two from that of the bride.groom have asked the parties concerned in marriage whether they accept each other as husband and wife. Thrice they have asked the questions and thrice they have heard the bride and bride.groom say, 'I do.' The husband has agreed to sign the contract providing so much in his mahr."

This document being read and re-read, the quazi signs both papers. It also bears six or seven or eight other initials, including those of the father of the bride, of the father of the bride-groom and four shahids, witnesses. These witnesses must all be elderly men. Then the bride and the bride-groom put their names or the impressions of their left thumbs on the contract. This being done, all is quiet again and the qäzi or mufti (both terms mean the same) reads a chapter from the Koran, and those rules and regulations which are laid down in the "Traditions of $\mathrm{Mu}$ hammad." Then a short sermon is delivered which informs the young couple regarding their respective duties towards each other.

As soon as the ceremony is over, cries of "Be it ominous" - "Be it lucky" fill the air, and the bride is conveyed to her chamber again amidst showers of coins and flowers. The bride-groom retircs to his own apartment. The $q \bar{d} z i$ 
is given a thän-a piece of cloth about thirty yards longof gold cloth, some money, a turban, sweets and fruits; his work has been completed.

After the ceremony the bride-groom's mother takes charge of the bride, and all crowd to the bride's room, for another custom must be observed. Every lady is expected to come and see the bride unveiled, and give something in gold or silver in her hand as rimumagi- the gift for seeing the beautified face of the newly-married one.

Soon afterwards the bride's maids prepare a place in the largest hall of the house for another ceremony called Aina mushaf (Persian-Aina, mirror, charming and beautiful face, meaning a mirror in which a charming face is reflected). This is, perhaps, the oldest custom in connection with the wedding ceremony. A mirror is placed before the bride, and the bride.groom is asked to sit on the bride's left. A shawl is held over them, and the bride has to unveil and look in the mirror. Then husband and wife see each other's face for the first time. It is, as a matter of fact, their first real meeting. The bride is shy and does not open her eyes, and the bride's maids and others pass many humorous remarks, chaffing her freely.

A silver engraved bowl is then brought, with a little sherbet, and a plate of white rice pudding. The bridegroom is to drink a little of the sherbet and offer the bride a sip. Often she closes her lips tightly, but force is applied and a spoonful dropped into her mouth; so also with the rice pudding. Sherbet and rice must always be tasted first by the man. A shower of roses announces the termi. nation of this custom, and when the bride-groom attempts to rise he finds he is held down to the floor, a corner of his coat having been sewn to the carpet while he was engaged in Aina Mashaf. At this there is a roar of laughter. The offender is found, and is probably a younger sister of the bride. She refuses to undo the stitches unless a gold coin is given to her. As soon as this toll is paid, the bride- 
groom calls his attendants to bring his shoes, but it is found that one of them is missing. Some one declares that she knows who possesses the shoe and that it will be duly returned on payment of two gold coins.

The bride-groom is rescued from his tormentors after the payments are made.

Then he goes away and joins the concert of the merry. makers in the shadi khana. There his place is a dignified one, for he sits on the right-hand side of the head of the Clan. It is very amusing to sce the audience of merry* makers. The old men occupy seats next to the bridegroom; the other seats are graduated according to the age. No employecs are allowed to sit, and servants carry cups of green tea to whoever may want one. The elderly men are seen swaying from side to side accompanying a couplet from molanay rum, for they see the profound meanings in it. Some throw money to the singers. The youths on each side sit with gaping mouths and scribble down on the white floorcloth or pillow covers such couplets as strike them as particularly good, but they cannot read thcir writing when the concert is over. An eccentric old man yells out with closed eyes "bäz bekham, bäz bekham, saräd khüb ast," "Sing it again, sing it again, your voice and the song stir my very soul." The song is encored again and again, till the singer gets stupefied and forgets the couplets. In this manner affairs in the Song Hall progress from hour to hour. In the small hours of the morning you find instead of enthusiastic lovers of music, clumps of snorting youths lying rolled in their voluminous postins or fur coats, Some may have even used the carpets to keep themselves warm. The best singer has retired, and one who hisd already had two or three rounds is endeavouring to make people believe that his hoarse voice is musical.

At dawn comes another ceremony. It is announced that the bride is about to depart to her mother-in-law's house. All are roused and make ready to escort her. If 


\section{The Folk Life of Afghanistan.}

the house is not far distant the leader of the head of the Clan carries the bride in his arms, but perhaps a conveyance is used for this purpose. They all help the bride to mount the carriage, with bismillah-with the name of Allah-and imaim saimin-Saints be her guards. The bride thus accompanied with an old servant and an elderly lady and her sister or a friend depart in tears from her mother's house. Her mother is weeping bitterly.

The bride-groom follows his bride on horseback attired in his nuptial garments, and others, also on horses, make up a procession.

The dress usually worn by the Afghan bride-groom is not gaudy. It consists of a white or dove-grey silk turban adorned at the end with a few vertical golden stripes. He wears a loose garment like a dressing gown, called jubba, similar to that worn by the Arab Sheikhs. It is of black velvet or serge, there is gold work on the cuffs and on the dorsal surface of the arm near the shoulder, and a big leaf is embroidered on the back. Not infrequently, however, all work of ornamenting the jubba is done in red or blue silk.

A kamar.band is tied round his waist under his jubba, and in it is inserted a curved dagger. (Persian-kamar $=$ waist, band aband, meaning a band for the waist.) He Wears white baggy trousers with a thousand folds, something like the kind favoured by the Algerians. The shocs are most picturesque; they are like slippers, the toe point is curved up and tapers to a thread.

When the procession reaches the other house, the bridle is taken to her new apartments, where she will remain for two or three days. Then her mother will come to take her away to her paternal home for a week. Afterwards she settles down in her new home, and unpacks her cases.

Her staff of servants is provided by her husband, with an additional kanis (woman slave) or a ghuläm (man slave) from her parents. Her house is not a scparate one. The cooking is done in one kitchen for the whole family of her 
mother-in-law. There are, however, private apartments for her husband and herself. At meal times she has to be present at the family table. She becomes one of the family. An extra degree of bashfulness is considered a great quality among young maidens and more especially newlymarried women, and this quality is sometimes a drawback to them, for they cannot sit with others at the meals.

Messengers run from one house to another, from the bride to her mother, and from her to her daughter in turn, at all hours of the day and night. Some inquire about the family, others fetch a forgotten workbox, a third runs for fresh vegetables from the girl's own little garden, and so on.

Tasty dishes and newly baked bread are sent on to the homesick bride. The husband goes out after breakfast if he is well-to-do and has an hour or two in his karaiz (field), or shoulders his gun and goes to the woods to shoot. He comes home at lunch-time laden with all kinds of game. The wife is engaged putting her house in order till agha (the master or husband) returns.

Two or three months go past, but the bride during this time is not allowed to visit her mother; her mother, how. ever, can call and see her. In time a Function is held, and after it the young lady has permission to visit her parents in the house of her birth. This is termed $p \bar{a} w a z i$ (Persian$p \tilde{a}$, feet; $w \tilde{a z} i$, a corruption of azedzi, meaning to open, to free), "Freedom of the feet."

A few friends and relations are invited to breakfast by the bride's mother. They afterwards visit the bridegroom's house, and reading the Korann and showering flowers and sweets bring the young wife to her mother's house. There a feast is held and all remain till maghrib, or evening prayer, when the same body of people escort the young wife back to her husband. After this $p \bar{a} w a \bar{s} i$, she can visit her mother as often as she pleases, but on all occasions she has to receive the permission of her husband and mother-in-law, and they never refuse her. 
I now come to my last section, which deals with the passing of the Afghan from this life to the next.

\section{Customs, Religious Rites, Cerremonies of Burials.}

As soon as it is known that a man is about to dic, in African phraseology, the physicians have "declared their seply "-jawäb dädand, that the patient will not live long, the news spreads like fire, and relations begin to collect.

If the dying man has not made a will, he calls a qazi and dictates and signs one. The women folk dislike to hear of a will; the word is never uttered when anybody is unwell. It is equivalent to expressing an ill wish. If they inquire as to how the patient is, they generally say, "We have heard that the enemies of your hu: band are indisposed."

A dying man calls his sons, daughters and wife to his bedside. He makes a short speech to them in which he wishes them goodbye, and advises them to live in peace and harmony as they have done during his life-time. Then he places his hand on his wife's head and asks her to be considerate to her children, and appoints his eldest son as the head of the family. All weep most profusely. The dying man warns them-as a rule-that his soul will not rest in peace if they weep after his death or do not live together in harmony and peace.

When death at length comes loud wailing resounds through the Fort. Relations and servants weep profusely. Someone sits down near the dead person and reads the sura yäsin (one of the chapters of the Korann). Other members of the family and Clan come to join in the burial procession, and the house is soon quite full.

No one is allowed to go into the room where the dead person may be lying, a dim light burns there and two or three haffis or chanters of the Korãn by rote, read the suras in a low tone, while all without is wailing and crying. 
Some are wrapped in mournful silence. A man is at once dispatched to make the grave ready, another to bring white shrouds and incense and earthenwares. In a piece of ground in the family garden is dug a temporary grave, called lahd, and there the dead is washed and bathed. Then this grave is closed up and made green with tufts of grass.

Watcr carricrs and others engage themselves in the act of washing the corpse, and two or three near relations rub the body, while the water carrier spurts water from his mashk-a goat-skin containing water. The big toes of the dead person are tied with a strip of white muslin, and a white sheet is carricd right up to the head and knotted there. Benzoin burns all the time and the lahd is curtained all round. Then the wooden frame, like a bedstead, is brought forward, a white cloth is spread on it and the corpse, supported by six people, is transferred from the lahd board on to the bedstead. Two sheets cover the dead body and the corners are tied at the ends by white strips, and then the jenasa (the funeral) preparations are com. pleted.

A rose perfume is sprinkled over the jankza, no flowers are laid there, but in some families the outer cover of the bedstend is inscribed with verses from the Korãn. The burial takes place as soon as possible. A short prayer called, fatiha is read before lifting the bier, which is then carried on shoulders, the six nearest relatives supporting the bedstead, four at each corner and two in the middle; no one gocs in front of the janaza.

If the dead is a woman all the ceremonies are the same, but the washing, glusl (Persian-bath) is done by a female of the family, usually the mother or some other elderly person. The bier is then carried from the female quarters to the courtyard, where the funeral service is performed.

When people hear that So-and-so is dead they utter these sentences from the Koran: "Inna lillahd wa inno 


\section{The Folk Life of Afghanistan.}

alaih rajayun" (Arabic, "We are owned by God and to Him we must all return").

The funeral service is held in the courtyard or a ficld where large numbers of people may be able to pray. The bier is placed in front and all arranged in facing it. The imäm, or priest, leads the prayer. All fold their arms, one over the other, round their waist, direct their gaze down. wards at the words of allaho akbar-God is Great-from the imam, and a silent prayer is read for the peace of the
soul.

When the prayer is over the bier is carried to the grave, and all the mourners follow in procession, repeating prayers for the dead. The grave which has been prepared beforehand, consists of a ditch six feet deep, with an underis to bhamber running to the right side in which the body is to be placed. This chamber is called baghli or caress.

It is the custom that if anyone meets a funcral procession in his way, whether he knows the person or not, he must accompany it for at least forty steps and repeat the prayer for the dead. If he is in a carriage or riding a horse he must come down and join the mourners, and must not pass the jandza, but wait till the procession passes before he continues his journey.

When the bier reaches the grave, two men descend into the grave and the corpse is lowered gently, and placed in the chamber. The direction of the grave is determined according to the situation in which lies the Holy City, Mecca. The fect of the dead must be towards the west, and the liead to the east, the face being towards Mecca. When the men come out of the grave, a short prayer is repeated by nll who are standing round. Then the boards are placed in position and a mat laid over them and the earth is thrown in. All the mourners throw down handfuls of earth, and finally the grave is closed and a mound raised over it. A temporary grave-stone is erected and below it a small lamp burns feebly. Men are appointed to watch the grave 
and one or two Mullas having read-passages from the Koran, the party wend their way back to their respective homes.

It may be mentioned here that in some cases, the chamber in which the body rests is constructed of bricks and a space two feet high is left below the covering planks. It is believed that when the horn is sounded on the Day of Judgment, all the dead will arise. It is desired that when they awake, their eyes will gaze at the Holy Kaba at Mecca. The space left above the grave is the height of an average man when he sits erect, as everyone will sit when he hears the last summons.

The chambers of many graves are not lined with bricks, nor are any structures placed over them, for some people think that the body will have a hard struggle in leaving the grave at the Blowing of the Horn, if the graves are covered with cement and stones.

After the burial the chief mourners return to the house of the deceased. There the head of the Clan addresses the women folk, counselling them not to grieve, for it was the will of Allah that So-and-so has died and that his soul should be accorded Divine Acceptance. Then the party is asked to dine, and after a prayer they disperse.

The widow and the female relatives of the deceased wear no colours and no ornaments. Some widows never again use colours, but always appear in pure white without ornaments.

Feasts called jum'arain (Persian, of Thursday), are held cvery Thursday, and mourners are invited to dinner and to read the Korañ for the dead. Similar ceremonies are also observed on the fourteenth day and the forticth day after the death. On the fortieth day, which is called chahlum, friends and relations come from far and near to join in the mourning, and all go to the grave to pray there. The women attend on this occasion. When a relation comes from a distance to join in the chahlum, one who has not 


\section{The Folk Life of Afghanistan.}

been at the burial ceremony, he shakes hands with all and expresses sympathy.

Chahlum being over, there is no other formal function till a year has gone past. Then the mourning called säli (Persian, pertaining to year, yearly) is held. All relatives go to the grave and spend a whole day there in mourning. The lamp-lighting takes place each Thursday for long afterwards, and a Mulla may be appointed to read the Korän regularly over the grave for a number of years. On Fridays after the prayer, people visit the graveyard and read a portion of the Koran and send blessings to the soul of their relatives.

On Thursdays, after 'isha' (last prayer or night prayer), one may see a whole household sitting round the lahd, where the body of the dead has been washed. Chapters from the Koran are read for the benefit of the departed. The scene is one of great solemnity and is very touching. The mourners read a portion of the Holy Texts and pause with uplifted besecching hands. With deep reverence they first send the blessings of the Koran to the soul of the Prophet Muhammad. Then very tenderly, their sorrow sweetened by piety, they send heart-felt blessings to the soul of their own remembered dead. So do Love and Duty endure, for Death cannot cause them to wither and decay.

Ikbal Ali Shah, 